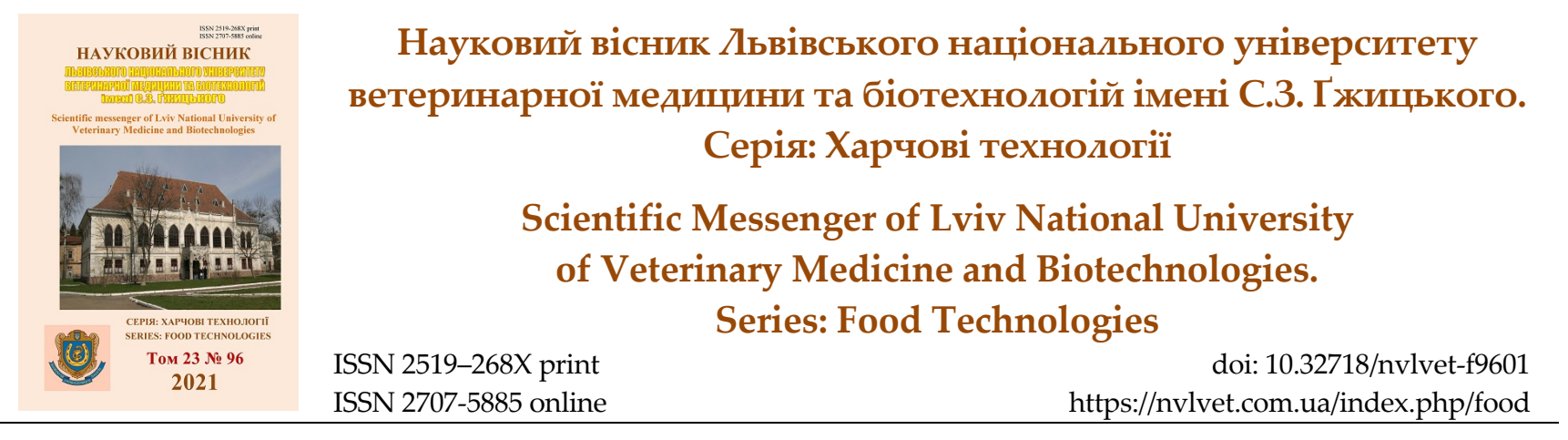

UDC 664.64.022.39

\title{
Research of technological properties of bread made with the addition of beet kvass
}

\author{
H. Karpyk, M. Kukhtyn, V. Selskyi, I. Nazarko, O. Pokotylo, M. Haidamaka \\ Ternopil Ivan Puluj National Technical University, Ternopil, Ukraine
}

Article info

Received 16.03.2021

Received in revised form 19.04.2021

Accepted 20.04.2021

Ternopil Ivan Puluj National Technical University, Ternopil, Ruska Str., 56, Ternopil, 46001, Ukraine.

Tel.: +38-097-239-20-57

E-mail:kuchtynnic@gmail.com
Karpyk, H., Kukhtyn, M., Selskyi, V., Nazarko, I., Pokotylo, O., \& Haidamaka, M. (2021). Research of technological properties of bread made with the addition of beet kvass. Scientific Messenger of Lviv National University of Veterinary Medicine and Biotechnologies. Series: Food Technologies, 23(96), 3-7. doi: 10.32718/nvlvet-f9601

The issue of healthy eating has always been relevant, especially this problem has been exacerbated by the rapid development of food technology and the production of a significant number of semi-finished products. As a result, there is a need to develop new types of food, including unleavened and low-calorie bread, bakery products enriched with vitamins, minerals, plant supplements. The aim of the work was to substantiate the technology of bread production with the use of beet kvass and to investigate the physicochemical quality indicators of experimental samples of finished products. Technological indicators that characterize the quality of bread: moisture, porosity, crumbliness, acidity were determined by generally accepted methods. Bread made with beet kvass has been found to have well-developed crumb porosity, does not crumble for a long time, hardens slowly, and is resistant to microbiological spoilage. The crumb is not deformed and elastic when pressed. Replacing part of the water during the kneading of wheat dough with beet kvass (50\% by weight of flour) makes it possible to intensify the maturation of semifinished products, both in traditional and accelerated technologies, to create a more complete nutrient medium for yeast activation, to obtain high quality bakery products storage. It has also been found that during the storage of bread, the hydrophilic properties of the crumb, its crumbliness changes slightly. The drying process is most intense during the first day, then slows down.

Key words: bread with beet kvass, moisture, porosity, crumbliness, acidity.

\section{Дослідження технологічних додаванням бурякового квасу \\ властивостей хліба виготовленого 3}

\author{
Г. В. Карпик, М. Д. Кухтин, В. Р. Сельський, І. С. Назарко, О. С. Покотило, М. Г. Гайдамака
}

Тернопільський національний технічний університет імені І. Пулюя, м. Тернопіль, Украӥна

\footnotetext{
Питання здорового харчування завжди було актуальним, особливо ияя проблема загострилася із стрімким розвитком харчових технологій та виробництва значної кількості напівфабрикатів. Внаслідок иього виникає необхідність у розроблені нових видів харчових продуктів, зокрема бездріжджового та низькокалорійного хліба, хлібобулочних виробів збагачених вітамінами, мінералами, рослинними добавками. Метою роботи було обтрунтувати технологію виробництва хліба з використанням бурякового квасу та дослідити фізико-хімічні показники якості дослідних зразків готових виробів. Технологічні показники, які характеризують якість хліба: вологість, пористість, крихтуватість, кислотність визначали загально прийнятими методами. Встановлено, щчо хліб виготовлений з використанням бурякового квасу має добре розвинену пористість м'якушки, вона не кришиться тривалий час, повільно черствіє, є стійкою до мікробіологічного псування. М'якушка під час натискання не деформується та еластична. Заміна частини води під час замішування пшеничного тіста на буряковий квас (50 \% до маси борошна) дає можливість інтенсифікувати дозрівання напівфабрикатів, як у традиційних, так і прискорених технологіях, створити більш повночінне поживне середовище для активації дріжджів, отримати хлібобулочні вироби високої якості з довиим терміном зберігання. Також встановлено, щьо під час зберігання хліба гідрофільні властивості м'якушки, ї̈ крихтуватість змінюються незначно. Прочес усихання найбільш інтенсивно відбувається протягом першої доби, далі сповільнюється.
} 
Ключові слова: хліб з буряковим квасом, вологість, пористість, крихтуватість, кислотність.

\section{Вступ}

Завданням сучасної хлібопекарської промисловості є розроблення нових видів продуктів функціонального спрямування. У ряді харчових виробництв є досвід виготовлення ферментованих продуктів. До них належать кефір, сметана, квашені овочі та їх суміші, квас, фруктові та овочеві напої тощо (Drobot \& Sylchuk, 2016; Kukhtyn et al., 2018; Savchenko \& Kalinichenko, 2019). Такі продукти є найбільш повноцінними 3 огляду на біохімічний та мікробіологічний склад, адже в процесі бродіння накопичується ряд біологічно активних речовин (Yazar \& Tavman, 2012; Lialyk et al., 2020). Останнім часом у рецептурах для виготовлення хлібобулочних виробів використовують нетрадиційну рослинну сировину (різні види патоки, морепродукти, ферментні препарати, рослинні добавки, тощо) для поліпшення органолептичних властивостей і підвищення їх біологічної цінності (Iorgachova \& Lebedenko, 2015; Mis et al., 2017). Тобто, пропонується використання рослинної сировини, яка багата білками, харчовими волокнами, вітамінами різних груп, антиоксидантами, мінеральними речовинами (Zheltok, 2011; Pashova, et al., 2018). Проте важливо включати у рецептурний склад інгредієнти, які не тільки позитивно впливають на організм споживачів, але й покращують технологічні властивості напівфабрикатів та готових виробів, зокрема впливають на активність заквасочних культур і хід біохімічних змін у тісті в процесі виробництва.

У дослідженнях (Hrushkovska et al., 2019) повідомляється, що додавання до борошна складників, які позитивно впливають на розвиток молочнокислих мікроорганізмів, або чистих культур даних бактерій сприяє отриманню рідкої житньої закваски 3 підйомною силою 20-25 хв і кислотністю - 22 град. При цьому виявлено, що найкраще впливали на поліпшення підйомної сили і кислотності культури молочнокислих паличок Lactobacillus buchneri. Закваски із вмістом даних бактерій забезпечували більш виражений аромат через 5 діб зберігання, порівняно із свіжими заквасками. Також наводяться дані (Cheliabiieva \& Sosedova, 2018), що включення в рецептуру житньопшеничного хліба борошна сочевиці підвищує його харчову цінність та якість готового продукту. Зокрема, такий хліб відзначався надзвичайно приємним, м'яким смаком, був ледь кислуватий, не прісний та відповідав нормативним вимогам до даного виду виробів.

Науковцями національного університету харчових технологій (Sylchuk et al., 2016) запропоновано в рецептуру житньо-пшеничного хліба, виготовленого за прискореною технологією, включити комплексні підкислювачі “Ефект плюс”, “Оптимальний 1” та “Оптимальний 2”, що містять лимонну кислоту та суху молочну сироватку, ферментні препарати. Такий захід дає можливість забезпечити оптимальні структурно-механічні властивості тіста завдяки досягненню необхідної кислотності й інактивації $\alpha$-амілази. Отри- маний хліб відповідав вимогам нормативної документації.

Проте, науковці (Stabnikova et al., 2008; Hrushkovska et al., 2019; Mayda et al., 2020) у своїх дослідженнях приходять до думки, що оптимальним способом вдосконалення технологічних властивостей тіста і якості хлібобулочних виробів є використання природньої сировини, яка покращує мікробіологічні і біохімічні процеси в тісті, тобто пришвидшує ферментативні процеси.

Нами було запропоновано для підвищення біологічної цінності хліба і пришвидшення перебігу ферментативних процесів у напівфабрикатах включити у рецептуру квас із столового буряка. Даний напій $є$ джерелом натуральних органічних кислот, амінокислот, вітамінів, зокрема $\mathrm{C}$, мінеральних речовин (заліза, калію) та сприяє активному розвитку молочнокислих мікроорганізмів.

Метою роботи було обгрунтувати технологію виробництва хліба з використанням бурякового квасу та дослідити фізико-хімічні показники якості дослідних зразків готових виробів.

\section{Матеріал і методи досліджень}

Для приготування тіста використовували борошно пшеничне вищого сорту, цукор-пісок, дріжджі хлібопекарські пресовані, квас виготовлений із буряка столового сорту Бордо.

Масову частку вологи визначали прискореним стандартним методом за відношенням різниці маси м'якушки хліба до та після висушування до маси хліба. Пористість виробів визначали за загальноприйнятою методикою. Із середини зразка хліба, на відстані 1-1,5 см від скоринки гострим циліндричним ножем вирізали шматочок м'якушки певного об'єму, зважували його та, враховуючи густину безпористої маси м'якушки, розраховували пористість хліба, яку виражали у відсотках. Визначення кислотності здійснювали загальновизнаним титрометричним методом. Крихтуватість визначали на вібраційному змішувачі шляхом перемішування протягом 5 хв двох шматків м'якушки заданої маси. Крихти, отримані за рахунок тертя шматків, зважували та проводили розрахунок за відношенням маси крихт до маси шматків (Karpyk, 2016).

Статистичну обробку отриманих даних здійснено 3 використанням комп'ютерної програми Statistica 6.0 (StatSoftInc., USA). Отримані дані вважали достовірними при $\mathrm{P}<0,05$.

\section{Результати дослідження}

На першому етапі нами було теоретично обгрунтовано й експериментально апробовано рецептурний склад бурякового квасу та дослідних зразків хліба, які містили його в кількості 50 \% до маси борошна. Використовували чотири зразки квасу виготовленого за наступними рецептурами (табл. 1). 
Таблиця 1

Рецептурний склад зразків бурякового квасу

\begin{tabular}{lcccc}
\hline \multicolumn{1}{c}{ Сировина } & \multicolumn{3}{c}{ Рецептура, кг } \\
\cline { 2 - 5 } \multicolumn{1}{c}{ Суряк столовий сорту Бордо } & 1 & 2 & 3 & 4 \\
Вода & 0,7 & 0,7 & 0,7 & 0,7 \\
Цукор-пісок & 2,5 & 2,5 & 2,5 & 2,5 \\
Дріжджі хлібопекарські пресовані & 0,06 & 0,06 & 0,06 & 0,06 \\
Молочна сироватка & - & - & 0,1 & 0,1 \\
Сухий житній хліб & - & - & - & 0,05 \\
\hline
\end{tabular}

Для дослідження впливу ферментованого напою на хід технологічного процесу було проведено пробне лабораторне випікання та визначено показники якості готових виробів через 3 год після випікання та в про- цесі зберігання. Тісто готували безопарним способом. За контроль приймали хліб виготовлений без добавок. На рис. 1 наведено зображення тіста та контрольного і дослідного зразка № 4 з квасом буряка столового.

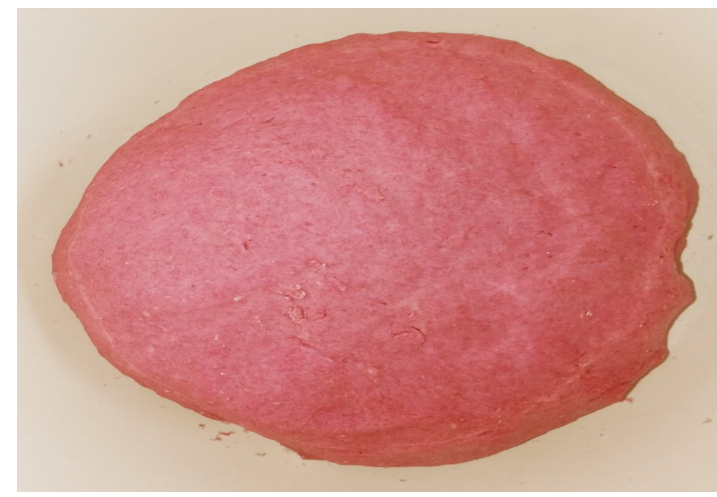

а) тісто з буряковим квасом

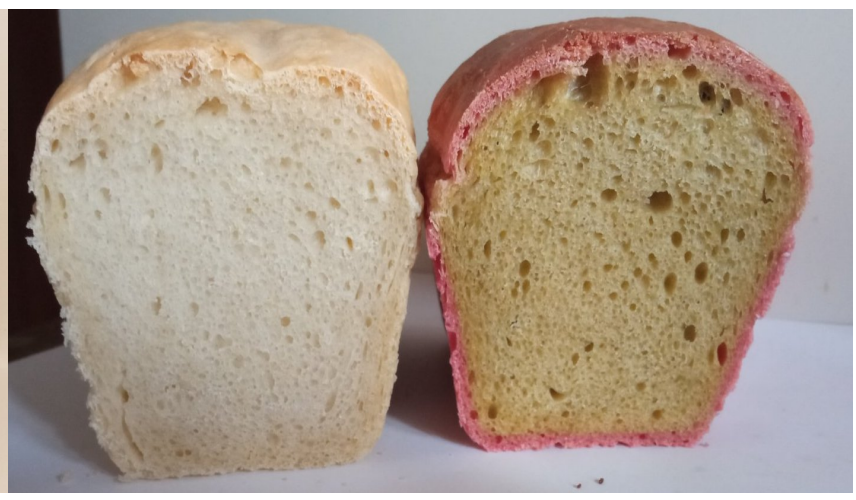

б) контрольний і дослідний зразок хліба

Рис. 1 (a, б). Тісто та зразок хліба із додаванням квасу з буряка столового

Як видно з рис. 1б, органолептичні показники дослідних зразків хліба з вмістом бурякового квасу значно відрізнялись від контрольного зразка. Так, спостерігали рожеве забарвлення скоринки та жовтуватий
3 коричневим відтінком колір м'якушки. Вироби мали незвичний кислуватий смак. Результати дослідження фізико-хімічних показників якості хліба наведено в табл. 2.

Таблиця 2

Фізико-хімічні показники якості дослідних зразків хліба з додаванням бурякового квасу

\begin{tabular}{lrrrrr}
\hline \multicolumn{1}{c}{ Показники } & \multicolumn{5}{c}{ Зразки хліба } \\
\cline { 2 - 6 } & контроль & \multicolumn{1}{c}{ №1 } & №2 & \multicolumn{1}{c}{ №3 } & $44,0 \pm 0,2$ \\
\hline Вологість, \% & $44,0 \pm 0,2$ & $43,5 \pm 0,2$ & $43,5 \pm 0,2$ & $44,0 \pm 0,2$ & $73,0 \pm 1,0$ \\
Пористість, \% & $72,0 \pm 0,5$ & $69,0 \pm 0,5$ & $69,0 \pm 0,5$ & $71,0 \pm 0,5$ & $1,3 \pm 0,1^{*}$ \\
Крихтуватість, \% & $2,6 \pm 0,1$ & $0,7 \pm 0,1$ & $0,7 \pm 0,1$ & $1,1 \pm 0,1^{*}$ & $4,2 \pm 0,1^{*}$ \\
Кислотність, град. & $2,5 \pm 0,2$ & $3,0 \pm 0,1$ & $3,0 \pm 0,1$ & $4,0 \pm 0,1^{*}$ & $4,0.1$
\end{tabular}

Примітка: *P $<0,05$ - порівнюючи з контрольним зразком

3 результатів досліджень наведених в табл. 2 видно, що за вмістом масової частки вологи дослідні зразки практично не відрізнялись. Однак вологість хліба, в склад якого входив квас без використання хлібопекарських дріжджів на 0,5 \% нижча порівняно 3 контролем.

За показником пористості зразок хліба № 4 мав найвище значення - 73,1\%, що більше на 4 град., порівняно із зразками № 1 і № 2 та на 3 град за зразок № 3. Високу пористість хліба у зразка № 4 ми пов'язуємо 3 інтенсивнішими бродильними процесами у тісті завдяки використанню бурякового квасу 3 молочною сироваткою. Слід відмітити, що м'якушка еластична у всіх зразках, під час натискання не деформується.
У зв’язку з тим, що зразки хліба № 3 і № 4 виготовленні із використанням квасу 3 хлібопекарськими дріжджами, а зразок № 4 ще із додаванням молочної сироватки, відповідно у даних виробах біохімічні зміни з накопиченням органічних кислот відбуваються швидше. Про це чітко вказують результати 3 визначення загальної кислотності, так найбільше значення кислотності відмічали саме у даних зразках хліба 4,0 град та 4,2 град, відповідно. Однак, незважаючи на дещо вищу кислотність зразка хліба № 4, в нього був м'якший смак та приємний аромат.

Необхідно відзначити відсутність значної кількості крихт у виробах з ферментованим напоєм. Зокрема, крихтуватість дослідних зразків хліба № 3 і № 4 була, 
в середньому в 2,0 рази $(\mathrm{P}<0,05)$ менша, порівняно 3 контрольним зразком без вмісту бурякового квасу.

Отже, аналізуючи результати досліджень встановили, що найкращі органолептичні та фізико-хімічні показники якості притаманні зразку хліба № 4, в склад якого входить буряковий квас з молочною сироваткою. Тому подальші дослідження проводили саме $з$ цим хлібом.
Враховуючи отримані результати, доцільно прослідкувати вплив ферментованого напою на черствіння виробів. Нами проведено визначення наступних показників: кількість води, яку поглинає м'якушка, крихтуватість, вологість, пористість. Хліб зберігали в кімнатних умовах при температурі $19 \pm 2{ }^{\circ} \mathrm{C}$ протягом трьох діб.

Результати дослідження наведено в табл. 3.

Таблиця 3

Показники якості хліба з буряковим квасом у процесі зберігання

\begin{tabular}{lcccc}
\hline \multicolumn{1}{c}{ Показники } & \multicolumn{4}{c}{ Тривалість зберігання } \\
\cline { 2 - 5 } \multicolumn{1}{c}{ З год } & 24 год & 2 доби & 3 доби \\
\hline Вологість, \% & $44,0 \pm 0,2$ & $43,6 \pm 0,2$ & $43,2 \pm 0,2$ & $42,4 \pm 0,1$ \\
Пористість, \% & $73,0 \pm 0,2$ & $71,2 \pm 0,1$ & $70,4 \pm 0,1$ & $69,8 \pm 0,1$ \\
Крихтуватість, \% & $1,3 \pm 0,1$ & $1,4 \pm 0,1$ & $1,6 \pm 0,1$ & $1,6 \pm 0,1$ \\
Набухання, \% & $357 \pm 2$ & $350 \pm 2$ & $339 \pm 2$ & $321 \pm 2$ \\
\hline
\end{tabular}

Як свідчать результати досліджень, під час зберігання хліба гідрофільні властивості м'якушки, ії крихтуватість змінюються незначно. Процес усихання найбільш інтенсивно відбувається протягом першої доби, далі сповільнюється. На кінець третьої доби зберігання м'якушка хліба набуває дещо жорсткішої структури.

Необхідно відзначити, що присутність значної кількості органічних кислот надає хлібу специфічного кислуватого смаку, який посилюється в процесі зберігання.

Таким чином, хліб виготовлений з використанням бурякового квасу має добре розвинену пористість м'якушки, вона не кришиться тривалий час, повільно черствіє, є стійкою до мікробіологічного псування. Заміна частини води під час замішування пшеничного тіста на буряковий квас (50 \% до маси борошна) дає можливість створити більш повноцінне поживне середовище для активації дріжджів, скоротити тривалість дозрівання напівфабрикатів, отримати хлібобулочні вироби високої якості з довшим терміном зберігання.

\section{Обговорення}

Питання здорового харчування завжди було актуальним, особливо дана проблема загострилася із стрімким розвитком харчових технологій і хімії. Внаслідок цього виникає необхідність у розроблені нових видів харчових продуктів, зокрема хлібобулочних виробів збагачених вітамінами, мінералами, рослинними добавками, бездріжджового та низькокалорійного хліба (Mis et al., 2017; Stabnikova et al., 2019; Soliman et al., 2019). Для вирішення актуальних проблем галузі, підвищення фізіологічних властивостей та безпечності виробів (Iorgacheva \& Lebedenko, 2014) запропоновано використання фітодобавок. Вони можуть бути використані й для вдосконалення прискорених способів приготування тіста, національних виробів та спеціального призначення. Дані добавки доцільно застосовувати для підвищення якості хлібобулочних виробів з борошна пониженої якості й попередження мікробіологічного та окислювального псування.
Ми пропонуємо застосовувати як добавку що підвищує харчову цінність - буряковий квас. У виробництві хлібобулочних виробів даний коренеплід практично не використовується. Як відомо, речовини, що містяться в складі цієї рослини позитивно впливають на організм людини: зміцнюють стінки капілярів, нормалізують кров'яний тиск, чинять спазмолітичну дію. Окрім того, пектинові речовини захищають організм від негативного впливу радіоактивних речовин та важких металів. Нами запропонована рецептура ферментованого напою на основі буряка в склад якої можуть входити дріжджі хлібопекарські, сухий житній хліб, молочна сироватка.

Проведено дослідження застосування в технології хліба екстрактів глоду та шипшини на воді або молочній сироватці (Lebedenko et al., 2014). Їх використання дає можливість створити оптимальні умови для життєдіяльності дріжджів і молочнокислих бактерій завдяки збагаченню напівфабрикатів поживними речовинами, біогенними та олігобіогенними елементами, органічними кислотами. Отриманий хліб мав високі показники якості та подовжений термін зберігання.

У наших дослідженнях встановлено, що виготовлення пшеничного тіста на буряковому квасі 3 додаванням молочної сироватки дозволяє отримати хліб, який за фізико-хімічними показниками перевищує контрольний зразок. Зокрема, завдяки наявності у напої вітамінів групи В, мінеральних елементів: магнію, калію, йоду марганцю, заліза та інших біологічно-активних речовин відбувається інтенсифікація дріжджової мікрофлори у тісті, що прискорює бродильні процеси і швидкість його дозрівання. Крім того, присутність молочної сироватки під час замішування тіста сприяє розвитку корисних молочнокислих паличок, які підвищують його кислотність. Зокрема, кислотність дослідного зразка хліба № 4 замішаного на буряковому квасі з молочною сироваткою становила 4,2 $\pm 0,1$ град, що на один градус більше, ніж у контрольному зразку. Як відомо, підвищення кислотності пшеничного хліба добре впливає на термін його зберігання і стійкість до збудників псування. 
Отже, за нашими даними заміна частини води буряковим квасом під час замішування пшеничного тіста, дає можливість скоротити тривалість його приготування, продовжити час зберігання готової продукції та підвищити харчову цінність.

\section{Висновки}

Запропоновано технологію виробництва пшеничного хліба з додаванням бурякового квасу під час замішування тіста. Встановлено, що внесення 50 \% ферментованого напою до маси борошна сприяє пришвидшенню дозрівання тіста, швидшому наростанню кислотності. Готовий хліб має добре розвинену пористість м'якушки, вона не кришиться тривалий час, повільно черствіє, є стійкою до мікробіологічного псування.

\section{References}

Cheliabiieva, V., \& Sosedova, E. (2018). Using of leaven of spontaneous fermentation and of flour leguminous in bread production. Technical sciences and technologies, 3(13), 251-257.doi: 10.25140/2411-5363-20183(13)-251-257.

Drobot, V. I., \& Sylchuk, T. A. (2016). Vykorystannia zakvasky spontannoho brodinnia pry vyrobnytstvi zhytno-pshenychnoho khliba [Using spontaneous fermentation sourdough in the production of rye-wheat bread]. Naukovi pratsi NUXT - Scientific works of NUFT, 22(1), 180-184 (in Ukrainian).

Hrushkovska, A. O., Danylenko, S. H., Kryzhska, T. A., \& Khonkiv, M. O. (2019). Appplication of lactic acid bacteria on the indicators of rye source. Scientific notes of TNU named after VI Vernadsky, 30(69), 92-97. doi: 10.32838/2663-5941/2019.4-2/15.

Iorgachova, K. G., \& Lebedenko, T. E. (2015). Hlibobulochni virob iozdorovchogo priznachennia $\mathrm{z}$ vikoristanniam fitodobavok [Bakery products of health destination with the use of herbal supplements]. Kyiv: Pres (in Ukrainian).

Iorgacheva, E. G., \& Lebedenko, T. E. (2014). Potential of medicinal and aromatic plants to increase the quality of wheat bread. Eastern-European Journal of Enterprise Technologies, 2(12(68), 101-108. doi: 10.15587/1729-4061.2014.23672.

Karpyk, H. V. (2016). Metodychni vkazivky do vykonannia laboratornykh robit $\mathrm{z}$ dystsypliny "Zahalni tekhnolohii kharchovykh vyrobnytstv" dlia studentiv vsikh form navchannia zanapriamom pidhotovky 6.051701 "Kharchovi tekhnolohii ta inzheneriia", spetsialnisti 181 "Kharchovi tekhnolohii". Ternopil: TNTU imeni Ivana Puliuia (in Ukrainian).

Kukhtyn, M., Vichko, O., Horyuk, Y., Shved, O., \& Novikov, V. (2018). Some probiotic characteristics of a fermented milk product based on microbiota of "Tibetan kefir grains" cultivated in Ukrainian household. Journal of Food Science and Technology, 55(1), 252 257. doi: 10.1007/s13197-017-2931-y.

Lebedenko, T. E., Kozhevnikova, V. O., \& Novichkova, T. P. (2014). Prospects of improvement of accelerated bread technologies by usage of dogrose and hawthorn. Technology Audit and Production Reserves, 3(5(17), 8-11. doi: 10.15587/2312-8372.2014.25351.

Lialyk, A., Pokotylo, O., Kukhtyn, M., Beyko, L., Horiuk, Y., Dobrovolska, S., \& Mazur, O. (2020). Fatty acid composition of curd spread with different flax oil content. Nova Biotechnologica et Chimica, 19(2), 216222. doi: $10.36547 /$ nbc.v19i2.776.

Mayda, N., Özkök, A., \& EcemBayram, N. (2020). Bee bread and bee pollen of different plant sources: determination of phenolic content, antioxidant activity, fatty acid and element profiles. Food Measure, 14, 17951809. doi: 10.1007/s11694-020-00427-y.

Mis, A., Nawrocka, A., \& Dziki, D. (2017). Behaviour of Dietary Fibre Supplements During Bread DoughDevelopment Evaluated Using Novel Farinograph Curve Analysis. Food Bioprocess Technology, 10, 10311041. doi: 10.1007/s11947-017-1881-8.

Pashova, N. V., Voloshchuk, H. I., Hrehirchak, N. M., \& Karpyk H. V. (2018). Vplyv boroshna znezhyrenoho nasinnia oliinykh kultur ta poroshku topinambura na yakist ta bezpechnist zhytnoho khliba [Effect of defatted flour of oilseeds and topinambur flour on rye bread quality and safety]. Prodovolchi resursy, 11, 139-147 (in Ukrainian).

Savchenko, O., \& Kalinichenko, Y. (2019). Technology of manufacturing rye and wheat sourdough bread with the use of basil. Technical sciences and technologies, 4(18), 183-191. doi: 10.25140/2411-5363-2019-4(18)-183-191.

Stabnikova, O., Antoniuk, M., \& Stabnikov, V. (2019). Ukrainian Dietary Bread with Selenium-Enriched Soya Malt. Plant Foods for Human Nutrition, 74, 157163. doi: 10.1007/s11130-019-00731-z.

Stabnikova, O., Ivanov, V., Larionova, I., Stabnikov, V., Bryszewska, M. A., \& Lewis, J. (2008). Ukrainian dietary bakery product with selenium-enriched yeast. LWT-Food SciT echnol, 41, 890-895. doi: 10.1016/j.lwt.2007.05.021.

Soliman, A. S., Abbas, M. S., \& Abol-Ella, M. F. (2019). Towards bridging wheat gap in Egypt by using cassava, quinoa and guar as supplements for the production of balady bread. Food Measure, 13, 1873-1883. doi: 10.1007/s11694-019-00106-7.

Sylchuk, T., Zuiko, V., \& Tsyrulnikova, V. (2016). Doslidzhennia zminy fizychnykh vlastyvostei zhytnopshenychoho tista pry vykorystanni pidkysliuvachiv [Investigation of changes in the physical properties of ryewheat dough when using acidifiers]. Food Science and Technology, 10(1), 49-53. doi: 10.21691/fst.v10i1.79.

Yazar, G., \& Tavman, S. (2012). Functional and Technological aspects of sourdough fermentation with lactobacillus sanfranciscensis. Food Eng Rev, 4, 171-190. doi: 10.1007/s12393-012-9052-1.

Zheltok, K. V. (2011). Ispolzovanie oblepihii shipovnika v kachestve vitaminizirovannoy dobavki v proizvodstve hlebo-bulochnih izdeliy [The use of sea buckthorn and rose hips as a fortified supplement in the production of bakery products]. Uspehov sovremennogo estestvoznaniia - Successes of modern science, 7, 111 (in Russian). 